\title{
INTRODUCTION
}

The concept of indivisibility has been an important subject of academic inquiry in the field of international human rights law. Attestations around the interrelationship of civil and political rights, on the one hand, and economic and social rights, on the other, have somewhat turned away its appeal. The present article takes this discussion further by drawing upon the Convention on the Rights of Persons with Disabilities (CRPD) adopted in $2006 .{ }^{1}$

This article suggests that the CRPD has opened up a new understanding of the indivisibility of human rights. The Convention has pushed boundaries as its interpretation directly undercuts any attempt to apply the division into civil and political and economic and social rights. The mutual inextricability of both sets of rights turns out to be an integral feature of the rights protected by this Convention.

Several scholars have made the claim that the distinction between the two sets of rights has actually been blurred in the CRPD. ${ }^{2}$ Through legal and doctrinal analysis, the article goes a step further by both investigating the validity of this claim and by delving into what the blurring of the distinction between the two sets of rights means for the concept of indivisibility. Taking rights usually assigned to each of these sets as an example, it demonstrates that, while the Convention undermines any possible categorization into two distinct sets of rights, it is important to be mindful of such a blurring for the purpose of bringing about the participation of disabled people in society. This article goes on to examine both the practical and theoretical implications of the proposed understanding of indivisibility for international human rights law. Extending these implications above and beyond the issue of disability, it presses for a deemphasis upon the different categories of human rights in favour of an emphasis upon their real and actual enjoyment. The Convention itself thus provides for a real world relocation of indivisibility, which offers indeed a fresh perspective on the field. The article thereby hopes to place more at the centre of academic enquiry those issues that need to be addressed in order to make human rights more of a reality.

While the role of States in implementing human rights is explored, the question of the judicial enforceability of economic and social rights is left aside, not just because it has attracted a lot of attention in the literature to date, ${ }^{3}$ but also because this judicial enforceability is unlikely to have as yet a sufficiently broad range of application. ${ }^{4}$ This article furthermore only considers human rights as they are proclaimed universally, that is, through the human rights treaties adopted within the UN.

The article begins with a brief history of international human rights law to reveal how there emerges a questioning of the concept of divisibility. Relevant literature is taken into consideration throughout (section I). This is followed up by showing how the CRPD has overcome the distinction between the two sets of rights, and by highlighting the challenge this poses for the true interpretation of this Convention (section II). The article finally examines how the proposed understanding of indivisibility affects States' obligations while shifting attention to the real and actual enjoyment of human rights (section III).

\footnotetext{
${ }^{1}$ Convention on the Rights of Persons with Disabilities 2006, 46 ILM 443.

2 T Degener, '10 Years of Convention on the Rights of Persons with Disabilities' (2017) 35 NQHR 153-4; P Bartlett, 'The United Nations Convention on the Rights of Persons with Disabilities and Mental Health Law' (2012) 75 MLR 757; T van Boven, 'Categories of Rights' in D Moeckli, S Shah, S Sivakumaran and D Harris (eds), International Human Rights Law (2nd edn, Oxford University Press 2014) 148.

${ }^{3}$ See inter alia F Coomans (ed), Justiciability of Economic and Social Rights. Experiences from Domestic Systems (Intersentia 2006); M Langford (ed), Social Rights Jurisprudence: Emerging Trends in International and Comparative Law (Cambridge University Press 2009).

${ }^{4}$ P Hunt et al, 'Implementation of Economic, Social and Cultural Rights' in S Sheeran and N Rodley (eds), Routledge Handbook of International Human Rights Law (Routledge 2014) 545.
} 


\section{INDIVISIBILITY IN INTERNATIONAL HUMAN RIGHTS LAW}

\section{A. Civil and Political and Economic and Social Rights}

Fifty years ago, States adopted the International Covenant on Civil and Political Rights (ICCPR) and the International Covenant on Economic, Social and Cultural Rights (ICESCR). ${ }^{5}$ The original intention was not to draft two Covenants but to adopt a single binding international legal instrument after the Universal Declaration of Human Rights (UDHR). ${ }^{6}$ This was eventually rejected by the negotiators, the rationale being that there was a need for different methods for the implementation of human rights. ${ }^{7}$ While the civil and political rights were deemed legally enforceable, economic and social rights were regarded as aspirational goals. Therefore, a supervisory committee was set up for the ICCPR, whereas no such committee was established for the ICESCR. ${ }^{8}$ Since then human rights have generally been divided into two sets of rights, namely civil and political rights, named 'first-generation rights', and economic and social rights, named 'second-generation rights'.

Accordingly, the two sets of rights were supposed to result in different kinds of obligations. On the one hand, civil and political rights created 'negative obligations'. As provided for by Article 2(1) of the ICCPR, States Parties have 'to respect and to ensure to all individuals ... the rights recognized in the ... Covenant'. These obligations are of immediate effect, since the duty of State Parties is only to abstain from contravening the Covenant. On the other hand, economic and social rights entailed 'positive obligations'. According to Article 2(1) of the ICESCR, a State Party must 'take steps ... with a view to achieving progressively the full realization of the rights recognized in the ... Covenant ... to the maximum of its available resources'. Because of the scarcity of such resources, States Parties are allowed to achieve the objective over a certain period of time.

This obligation regime has been tempered by the UN treaty bodies in charge of monitoring the two Covenants. Concerning the ICCPR, the Human Rights Committee (HRC) considered that ' $[\mathrm{t}]$ he legal obligation under article 2 , at paragraph 1 , is both negative and positive in nature'. ${ }^{10}$ While civil and political rights entail immediate obligations, States Parties are not exempt from endeavouring to prevent their violation. ${ }^{11}$ The Committee on Economic, Social and Cultural Rights (CESCR) - which was subsequently created by ECOSOC $-{ }^{12}$ also advised that States Parties fulfil 'a minimum core obligation to ensure the satisfaction of, at the very

\footnotetext{
${ }^{5}$ International Covenant on Civil and Political Rights 1966, 999 UNTS 171; International Covenant on Economic, Social and Cultural Rights 1966, 993 UNTS 3.

${ }^{6}$ GA, Universal Declaration of Human Rights, 10 December 1948, A/RES/217.

${ }^{7}$ W Osiatyński, 'The Historical Development of Human Rights' in Sheeran and Rodley (n 4) 14-15; O De Schutter, International Human Rights Law (2nd edn, Cambridge University Press 2014) 18-19; E Riedel, G Giacca and C Golay, 'The Development of Economic, Social and Cultural Rights in International Law' in E Riedel, G Giacca and C Golay (eds), Economic, Social, and Cultural Rights in International Law Contemporary Issues and Challenges (Oxford University Press 2014) 7-9.

${ }^{8}$ Riedel, Giacca and Golay (n 7) 7.

${ }^{9}$ C Tomuschat, Human Rights: Between Idealism and Realism (Oxford University Press 2014) 136-9; M Sheinin, 'Characteristics of Human Rights Norms' in K Krause and M Scheinin (eds), International Protection of Human Rights: A Textbook (2nd edn, Åbo Akademi University 2009) 22. The former include the freedom from torture, right to liberty, right to privacy, right to access courts, freedom of opinion and freedom of assembly. The latter include the right to health, right to food, right to housing, right to education, right to work and right to social security.

${ }^{10}$ HRC, General Comment No 31: Nature of the General Legal Obligation Imposed on States Parties to the Covenant, 26 May 2006, CCPR/C/21/Rev.1/Add.13, para 6.

${ }^{11}$ A Seibert-Fohr, 'Domestic Implementation of the International Covenant on Civil and Political Rights Pursuant to its Article 2 para 2' (2001) 5 UNYB 414-16.

12 ECOSOC Res 1985/17, 28 May 1985.
} 
least, minimum essential levels of each of the rights' in the ICESCR. ${ }^{13}$ Economic and social rights create immediate obligations, which include the prohibition of discrimination. ${ }^{14}$

Such a reading of the two Covenants has mitigated the categorization of human rights into civil and political rights, on the one hand, and economic and social rights, on the other. In addition, a whole new range of literature started to deal with economic and social rights, which both improved the understanding of their content and helped to re-affirm their legal basis. ${ }^{15} \mathrm{~A}$ new obligation regime was conceptualized consisting of obligations to respect, protect and fulfil, which has proved a turning point. This tripartite typology was initially proposed and developed by Eide and Shue ${ }^{16}$ and subsequently applied by the CESCR Committee. ${ }^{17}$ The contention that the tripartite typology should be used for civil and political rights ${ }^{18}$ has also undermined the view that the two sets of rights bring about different kinds of obligations.

The adoption of several group-specific human rights treaties further contributed to weakening the division. The International Convention on the Elimination of All Forms of Racial Discrimination (ICERD) and the Convention on the Elimination of All Forms of Discrimination against Women (CEDAW) broke down the prohibition of discrimination in areas concerning civil a political and economic, social and cultural rights. ${ }^{19}$ The Convention on the Rights of the Child (CRC) was subsequently the first human rights treaty to bridge the two sets of rights. ${ }^{20}$ It provides not just a juxtaposition but a whole series of rights 'that encapsulate different aspects of both sets of rights thereby reflecting their indivisibility'. ${ }^{21}$ While the CRC has a specific provision on 'economic, social and cultural rights', ${ }^{22}$ it is difficult to accurately define the content of this category for most of the Convention rights. ${ }^{23}$ The incorporation of the different categories of human rights into international legal instruments

\footnotetext{
${ }^{13}$ CESCR, General Comment No 3: The Nature of State Parties Obligations (Art. 2, par. 1), 14 December 1990, E/1991/23, para 9.

${ }^{14}$ CESCR, General Comment No 20: Non-Discrimination in Economic, Social and Cultural Rights (art. 2, para 2), 29 May 2009, E/C.12/GC/20, para 7; 'Maastricht Guidelines on Violations of Economic, Social and Cultural Rights' (1998) 20 HRQ 691 (para 11).

15 See inter alia M Craven, The International Covenant on Economic, Social, and Cultural Rights: A Perspective on Its Development (Clarendon Press 1995); P Hunt, Reclaiming Social Rights. International and Comparative Perspectives (Ashgate 1996); A Eide, C Krause and A Rosas (eds), Economic, Social and Cultural Rights. A Textbook (2nd edn, Martinus Nijhoff Publishers 2001); I Merali and V Oosterveld (eds), Giving Meaning to Economic, Social, and Cultural Rights (University of Pennsylvania Press 2001); M Sepúlveda, The Nature of the Obligations under the International Covenant on Economic, Social and Cultural Rights (Intersentia 2003).

${ }^{16}$ A Eide, The Right to Adequate Food as a Human Right: Final Report, 7 July 1987, E/CN.4/Sub.2/1987/23; H Shue, Basic Rights: Subsistence, Affluence and U.S. Foreign Policy (2nd edn, Princeton University Press 1996) 52.

${ }^{17}$ CESCR, General Comment No 18: The right to work (art. 6), 24 November 2005, E/C.12/GC/18, paras 19-28; CESCR, General Comment No 15: The right to water (art. 11-12), 20 January 2003, E/C.12/2002/11, paras 1729; CESCR, General Comment No 14: The right to the highest attainable standard of health (art. 12), 11 August 2000, E/C.12/2000/4, paras 30-7; CESCR, General Comment No 13: The rights to education (art. 13), 8 December 1999, E/C.12/1999/10, para 46; CESCR, General Comment No 12: The right to adequate food (art. 11), 12 May 1999, E/C.12/1999/5, paras 14-15.

${ }^{18}$ R Künnemann, 'A Coherent Approach to Human Rights' (1995) 17 HRQ 327-31.

${ }^{19}$ International Convention on the Elimination of All Forms of Racial Discrimination 1965, 660 UNTS 195; Convention on the Elimination of All Forms of Discrimination against Women 1979, 1249 UNTS 13.

${ }^{20}$ Convention on the Rights of the Child 1989, 1577 UNTS 3.

${ }^{21}$ M Rishmawi, A Commentary on the United Nations Convention on the Rights of the Child, Article 4: The Nature of States Parties' Obligations (Martinus Nijhoff Publishers 2006) 16.

${ }^{22}$ Art 4 of the CRC provides that '[w]ith regard to economic, social and cultural rights, States Parties shall undertake all ... measures to the maximum extent of their available resources ... for the implementation of the rights recognized in the present Convention'

${ }^{23}$ Rishmawi (n 21) 16. As stated by the Committee on the Rights of the Child (CRC Committee), there is 'no simple or authoritative division of human rights in general or of Convention rights into the two categories' (CRC Committee, General Comment No 5: General measures of implementation of the Convention on the Rights of the Child, 27 November 2003, CRC/GC/2003/5, para 6).
} 
thus has become standard practice. ${ }^{24}$ It can also be observed in non-legally binding instruments, such as the Declaration on the Rights of Indigenous Peoples. However, the reconciliation of the two sets of rights raises important questions that have not yet been studied in detail.

With the adoption of the Optional Protocol to the ICESCR (OP-ICESCR) in 2006, the CESCR Committee eventually received the competence to handle individual complaints for alleged violations of the Covenant. ${ }^{25}$ This confirmed the judicial enforceability of economic and social rights, which had gradually gained ground through a high number of cases before domestic courts. ${ }^{26}$ Although the OP-ICESCR was only ratified by 23 States $^{27}$ and the HRC is much further ahead in exercising its quasi-judicial function, the means for ensuring compliance with the two sets of rights have been equalized, at least in theory.

\section{B. The Concept of Indivisibility}

The division of human rights into two sets of rights has been mitigated by other means. Despite the adoption of two distinct human rights treaties, States were keen to stress the common features of civil and political rights, on the one hand, and economic and social rights, on the other. While it was stated that the two sets of rights create similar kinds of obligations, it was in addition put forward that all human rights are indivisibly connected to each other. This indivisibility of human rights has been seen as proof of the interrelationship between both sets of rights. It reached a milestone with the World Conference on Human Rights held in 1993. The ensuing Vienna Declaration and Programme of Action proclaimed that '[a]ll human rights are universal, indivisible and interdependent and interrelated'. ${ }^{28}$ This statement conveyed the guiding principle of human rights and has been repeated in several UN legal documents. ${ }^{29}$ It is therefore worth enquiring into its substance and soundness, starting with the concepts of universality as well as interdependency and interrelatedness and then entering into more detail in the treatment of that of indivisibility.

Universality results from the very notion of human rights, although it has come under attack by cultural relativism. It has gradually been acknowledged that both views are not mutually exclusive and that universality does not prevent cultural particularities from being taken into account. ${ }^{30}$ Both universality and relativity, therefore, are essential to understand the notion of human rights. ${ }^{31}$

The fact that human rights are 'interdependent and interrelated' stresses their mutual reinforcement. The interdependency and interrelatedness of human rights are provided for in the preamble of both the ICCPR and the ICESCR, and were thrown into relief when it was decided to draft two Covenants. ${ }^{32}$ This interdependence and interrelatedness can easily be

\footnotetext{
${ }^{24}$ I Cismas, 'The Intersection of Economic, Social and Cultural Rights' in Riedel, Giacca and Golay (n 7) 455-6.

${ }^{25}$ Optional Protocol to the International Covenant on Economic, Social and Cultural Rights, 10 December 2008, A/RES/63/117.

${ }^{26}$ Hunt et al (n 4) 553.

${ }^{27}$ See $<$ https://treaties.un.org/Pages/ViewDetails.aspx?src=IND\&mtdsg_no=IV-3-a\&chapter=4\&clang= en $>$.

${ }^{28}$ World Conference on Human Rights, Vienna Declaration and Programme of Action, A/Conf.157/23, 25 June 1993, Part II, para 5.

${ }^{29}$ GA, World Summit Outcome, 24 October 2005, A/RES/60/1, paras 13 and 120; GA, Res 60/251: Human Rights Council, 15 March 2006, A/RES/60/251, Preamble; HRC, Res 5/1: Institution-building of the United Nations Human Rights Council, 18 June 2007, A/HRC/RES/5/1, Preamble.

${ }^{30}$ Tomuschat (n 9) 68-70; M Freeman, 'Universalism of Human Rights and Cultural Relativism' in Sheeran and Rodley (n 4) 54-7; F de Varennes, 'The Fallacies in the "Universalism Versus Cultural Relativism" Debate in Human Rights Law’ (2006) 7 Asia Pac J Hum Right Law 76-82.

${ }^{31} \mathrm{~J}$ Donnelly, Universal Human Rights in Theory and Practice (3rd edn, Cornell University Press 2013).

32 C Scott, 'Interdependence and Permeability of Human Rights Norms: Towards a Partial Fusion of the International Covenants on Human Rights' (1989) 27 Osgoode Hall LJ 798-802.
} 
illustrated in practice ${ }^{33}$ with some rights having distinct aspects that come under the remit of both sets of rights. ${ }^{34}$

In contrast, the concept of indivisibility remains much debated and its meaning is still contentious. There are two dominant approaches to this concept that have followed each other chronologically.

The first approach to the concept maintains that civil and political and economic and social rights have equal value. ${ }^{35}$ This is the traditional approach which asserts that there can be no hierarchy between the two sets of rights. This was expressed in the Teheran Proclamation on Human Rights, which stated that '[s]ince human rights and fundamental freedoms are indivisible, the full realization of civil and political rights without the enjoyment of economic and social rights is impossible'. ${ }^{36}$ Similarly, it has been argued that economic and social rights cannot be implemented without guaranteeing civil and political rights. ${ }^{37}$ Setting one set of rights in precedence over the other is ineffective, while neglecting this same set of rights hinders the fulfilment of the other. Both sets of rights cannot be but examined together.

The problem with this way of understanding indivisibility is that it does not reflect current practice. UN treaty bodies have fallen short of investigating the two sets of rights jointly or, notwithstanding good intentions, have done so in a way that is largely expository. The HRC has not paid any attention to their interrelationship. ${ }^{38}$ The CESCR Committee has done so very briefly with a view to highlighting indivisibility. ${ }^{39}$ The Committee on the Rights of the Child (CRC Committee) has not examined how both sets of rights are related, ${ }^{40}$ in contrast to the Committee on the Rights of Persons with Disabilities (CRPD Committee). ${ }^{41}$ Most textbooks moreover continue to discuss economic and social rights separately from civil and political rights, ${ }^{42}$ though there are a few exceptions that combine the two sets of right. ${ }^{43}$ There is thus

\footnotetext{
${ }^{33}$ For instance, one cannot exercise the freedom of expression and freedom of assembly without the right to an adequate standard of living or exercise the right to education and right to work without the freedom of expression and freedom of association.

${ }^{34}$ For instance, the right to education has both a 'social aspect' and a 'freedom aspect', the last of which concerns the choice of education, and the right to work has both economic and political dimensions, via the right to form trade unions which is protected by the two Covenant.

${ }^{35}$ J-P Thérien and P Joly, "“All Human Rights for All”: The United Nations and Human Rights in the Post-Cold War Era' (2014) 36 HRQ 381-2.

${ }^{36}$ International Conference on Human Rights, Proclamation of Teheran. Final Act of the International Conference on Human Rights, 22 April to 13 May 1968, A/CONF. 32/41 at 3, para 13.

${ }^{37}$ A Sen, Development as Freedom (Oxford University Press 1999) 149-51; O Guariglia, 'Enforcing Economic and Social Human Rights' in T Pogge (ed), Freedom from Poverty as a Human Right: Who Owes What to the Very Poor? (Oxford University Press 2007) 353.

${ }^{38} \mathrm{HRC}$, General Comment No 35. Article 9 (Liberty and security of person), 16 December 2014, CCPR/C/GC/35, paras 53-68; HRC, General Comment No 32. Article 14 (Right to equality before courts and tribunals and to a fair trial), 23 August 2007, CCPR/C/GC/32, paras 58-65.

${ }^{39}$ CESCR Committee, General Comment No 22 on the right to sexual and reproductive health (art. 12), 2 May 2016, E/C.12/GC/22, para 10; CESCR Committee, General Comment No 21 on the right of everyone to take part in cultural life (art. 15), 21 December 2009, E/C.12/GC/21, para 3.

${ }^{40} \mathrm{CRC}$ Committee, General comment No 19 on public budgeting for the realization of children's rights (art. 4), 20 July 2016, CRC/C/GC/19, para 30.

${ }^{41}$ CRPD Committee, General comment No 1. Article 12: Equal recognition before the law, 19 May 2014, CRPD/C/GC/1, paras 31-49; CRPD Committee, General comment No 2. Article 9: Accessibility, 22 May 2014, $\mathrm{CRPD} / \mathrm{C} / \mathrm{GC} / 2$, paras 34-48.

${ }^{42} \mathrm{~J}$ Steiner, P Alston and R Goodman, International Human Rights in Context: Law, Politics, Morals $\left(3^{\text {rd }}\right.$ edn, Oxford University Press 2007); J Rehman, International Human Right Law (Pearson 2010); I Bantekas and L Oette, International Human Rights Law and Practice (Cambridge University Press 2013); Krause and Scheinin (n 9); Sheeran and Rodley (n 4).

${ }^{43}$ D Shelton (ed), The Oxford Handbook of International Human Rights Law (Oxford University Press 2013); De Schutter (n 7); Moeckli, Shah, Sivakumaran and Harris (n 2).
} 
an evolutionary element in treating both sets of rights concurrently, although this remains a slow work in progress.

The second approach to the concept of indivisibility stresses that human rights are strongly interdependent. ${ }^{44}$ This modern approach claims that the implementation of a given right has an impact on all the others, and failure to take this into consideration impedes the implementation of human rights altogether. This has led to discussions as to whether the indivisibility of human rights involves mutual indispensability or just mutual usefulness. ${ }^{45}$ The question is where to set the threshold for the necessary recourse to indivisibility, thereby differentiating between 'full' and 'mere' interdependence or between a strong and a weak concept of indivisibility. Such a way of understanding indivisibility examines how civil and political and economic and social rights are actually intertwined, instead of just affirming the impossibility of giving priority to one set of rights over the other.

However, it not always the case that human rights are indivisible in the sense that they are mutually indispensable let alone mutually useful. There is evidence that such indivisibility can be greater between some of these rights and that some of them can be less connected. ${ }^{46}$ This implies that some sort of prioritization should be allowed and even recommended for those rights that have a more decisive effect on others. The indivisibility of human rights would be an exaggeration from an empirical point of view. A claim for the indivisibility of entire sets of rights would be even more implausible. ${ }^{47} \mathrm{Civil}$ and political and economic and social rights are not invariably dependent upon each other, whatever their interrelationship may be. Other factors impact on human rights as well, such as the level of democracy and the existence of internal conflict. ${ }^{48}$

The above discussion demonstrates that there is no agreement upon the pertinence of the two dominant approaches to the concept of indivisibility just outlined. Not only are the two sets of rights infrequently examined in combination but practice suggests that these sets of rights can be addressed individually. As a result, more is required to show the reality of indivisibility and to offer it a conceptualization that contributes to the advancement of human rights. Perhaps, the statement that '[a]ll human rights are universal, indivisible and interdependent and interrelated' has been replayed so many times that it has become a kind of self-sufficient slogan. This suggests that this statement may be more a wish than a reflection of reality. It appears reasonable to conclude that the indivisibility of human rights has been used rather widely as a means to compensate for the unfortunate division into two sets of rights, which itself was carried out against the spirit of the UDHR. ${ }^{49}$

\section{INDIVISIBILITY IN THE CRPD}

\section{A. Blurring of the Distinction between the Two Sets of Rights}

\footnotetext{
${ }^{44}$ J Nickel, 'Rethinking Indivisibility: Towards a Theory of Supporting Relations between Human Rights' (2008) 30 HRQ 987-91.

${ }^{45}$ P Gilabert, 'The Importance of Linkage Arguments for the Theory and Practice of Human Rights: A Response to James Nickel' (2010) 32 HRQ 429-30; J Nickel, 'Indivisibility and Linkage Arguments: A Reply to Gilabert' (2010) 32 HRQ 441-2.

${ }^{46}$ S Soiffer and D Rowlands, 'Examining the Indivisibility of Human Rights: A Statistical Analysis' (2016) JHR

$<$ http://www.tandfonline.com/doi/abs/10.1080/14754835.2016.1255549>.

${ }^{47}$ Nickel (n 44) 994-7.

${ }^{48}$ L Minkler and S Sweeney, 'On the Indivisibility and Interdependence of Basic Rights in Developing Countries' (2011) 33 HRQ 381-90.

49 J Whelan, Indivisible Human Rights. A History (Pennsylvania University Press 2010) 208.
} 
As the first human rights treaty of the $21^{\text {th }}$ century, the CRPD protects the human rights of disabled people. Proposed by Australia in 2002, ${ }^{50}$ it was adopted on 13 December 2006, and entered into force on 3 May 2008. By July 2018, there were 161 signatories and 177 parties to the Convention. ${ }^{51}$

The CRPD is said to build upon the social model of disability, ${ }^{52}$ which considers disability to be a consequence of societal organization. ${ }^{53}$ Even though it has been argued that the Convention surpasses this model, ${ }^{54}$ the Convention is concerned about physical and social barriers faced by disabled people. This is reflected in its scope of application, which includes people "who have long-term physical, mental, intellectual or sensory impairments which in interaction with various barriers may hinder their full and effective participation in society on an equal basis with others'. ${ }^{55}$ The CRPD proclaims a large set of rights for disabled people. Reality, however, is seldom far from consonant with the worthy objectives of the Convention. Disabled people have significantly fewer opportunities than others, and generally face harsh living conditions. ${ }^{56}$

As noted by Sen, disabled people often rely on more resources than others for achieving basic human functionings. ${ }^{57}$ In order to protect their human rights, measures must be adopted to address their specific situation. According to Mégret, the CRPD has done more than applying the rights protected by previous human rights treaties, which have been unable to cater for human differences. ${ }^{58}$ It has enriched the notion of human rights through ensuring that these rights are tailored to the particular needs of disabled people.

Echoing the Vienna Declaration and Programme of Action, the CRPD's Preamble reaffirms 'the universality, indivisibility, interdependence and interrelatedness of all human rights' ${ }^{59}$ This statement is a novum for a human rights treaty, ${ }^{60}$ but it directs attention to the particular significance of the concept of indivisibility for disabled people. Accordingly, the Convention has intermixed civil and political rights, on the one hand, and economic and social rights, on the other. Article 4(2) nonetheless provides that '[w]ith regard to economic, social and cultural rights, each State Party undertakes to take measures to the maximum of its available resources ... with a view to achieving progressively the full realization of these rights'. This provision has prima facie carried over the division into two sets of rights as an extension of the ICCPR and ICESCR.

In fact, the CRPD has done more than intermixing civil and political and economic and social rights; rather, it has literally done away with the distinction between the two sets of rights. It is futile to try and determine which set of rights the Convention rights individually belong to. Although the proposal to subject economic and social rights to the notion of progressive realization was not disputed during the negotiations, an attempt to list the rights

\footnotetext{
${ }^{50}$ G Quinn, 'Disability and Human Rights: A New Field in the United Nations' in Krause and Scheinin (n 9) 257.

${ }^{51} \mathrm{See}<$ https://www.un.org/development/desa/disabilities $>$.

${ }^{52}$ Bartlett (n 2) 758-61; P Harpur, 'Embracing the New Disability Rights Paradigm: The Importance of the Convention on the Rights of Persons with Disabilities' (2012) 27 Disability \& Society 3-4; R Kayess and P French, 'Out of Darkness into Light? Introducing the Convention on the Rights of Persons with Disabilities' (2008) 8 HRLR 24.

${ }^{53}$ M Oliver, Understanding Disability. From Theory to Practice ( $2^{\text {nd }}$ edn, Palgrave Macmillan 2009) 42-6.

${ }^{54} \mathrm{~T}$ Degener, 'A Human Rights Model of Disability' in P Blanck and E Flynn (eds), Routledge Handbook of Disability Law and Human Rights (Routledge 2016) 39-40.

${ }^{55}$ Art 1, CRPD.

${ }^{56}$ World Health Organization (WHO) and World Bank, World Report on Disability (WHO and World Bank 2011) $39-40$.

${ }^{57}$ Sen (n 37) 88; A Sen, Inequality Re-examined (Clarendon 1992) 256-7.

${ }^{58}$ F. Mégret, 'The Disabilities Convention: Human Rights of Persons with Disabilities or Disability Rights' (2008)

30 HRQ 595-6.

${ }^{59}$ Preamble (c), CRPD.

${ }^{60}$ The CRC's Preamble does not include such a statement.
} 
concerned eventually failed. ${ }^{61}$ The drafters did not clarify the scope of 'economic, social and cultural rights'. Instead, they wrote Article 4(2) in continuity with Article 4 of the CRC, which they took to have set a precedent for them. ${ }^{62}$

The CRPD also did more than just take up existing rights. In addition to articulating these rights specifically with regard to disabled people, the Convention has added - in Mégret's terms - a number of 'sui generis entitlements'. ${ }^{63}$ These 'sui generis entitlements' include aspects that were not anticipated in existing human rights treaties, in that they pertain to the inclusion of disabled people as well as the promotion of their independence and autonomy.

More importantly, the CRPD establishes a duty to provide disabled people with reasonable accommodation, and failure to do so is henceforth a form of discrimination. ${ }^{64}$ This duty, therefore, is of immediate application. The provision of reasonable accommodation is not only part of the general obligations, but is also repeated in particular provisions of the Convention. ${ }^{65}$ Such provision applies to both civil and political and economic and social rights. ${ }^{66}$ The prohibition of discrimination, by its extension to this duty, has infiltrated and narrowed the sphere of progressive realization, and thus contributed to a further weakening of the distinction between the two sets of rights.

Two particular examples of rights demonstrate the extent to which the two sets of rights have been conflated throughout the CRPD, and illustrate the way in which human rights are indivisible in this Convention. The first of these examples is supposed to be drawn mainly from civil and political rights, while the second is supposed to be drawn mainly from economic and social rights.

The first example is the right to independent living. Article 19 of the CRPD provides that disabled people have the right to 'choose their place of residence and where and with whom they live on an equal basis with others and are not obliged to live in a particular living arrangement' ${ }^{67}$ The main concern here is the practice of the widespread institutionalization of disabled people, a concern discounted by previous human rights treaties. This institutionalization constitutes a deprivation of liberty and can even amount to a form of mistreatment. ${ }^{68}$ There is therefore an overlap between the right to independent living and the right to freedom of movement, as well as the right to liberty and the prohibition of torture, which are considered to be part of civil and political rights.

The right to independent living extends even further, as disabled people need support that meets their individual needs if they are to be able to define their own living arrangements. According to the CRPD Committee, this right requires that States Parties 'take effective and appropriate measures to facilitate the full enjoyment of the right and full inclusion and participation of persons with disabilities in the community'. ${ }^{69}$ The CRPD indeed stipulates that disabled people must be able to access 'a range of in-, residential and other community support

\footnotetext{
${ }^{61}$ B Flóvenz, 'The Implementation of the UN Convention and the Development of Economic and Social Rights as Human Rights' in O Arnardóttir and G Quinn (eds), The UN Convention on the Rights of Persons with Disabilities. European and Scandinavian Perspectives (Martinus Nijhoff Publishers 2009) 265-6.

62 See n 22.

${ }^{63}$ Mégret (n 58) 506.

${ }^{64}$ Art 2, CRPD.

${ }^{65}$ Art 13(1) (access to justice), 14(2) (right to liberty and security of the person), 24(2)(c) (right to education) and 27(1)(i) (right to work), CRPD.

66 This had been confirmed earlier by the CESCR Committee (CESCR Committee, General Comment No 5 : Persons with Disabilities, 9 December 1994, E/1995/22, para 15).

${ }^{67}$ Art 19(a), CRPD.

${ }^{68} \mathrm{OHCHR}$, Thematic study on the right of persons with disabilities to live independently and be included in the community, 12 December 2014, A/HRC/28/37, paras 20-2; J Mendez, Report of the Special Rapporteur on torture and other cruel, inhuman or degrading treatment or punishment, 1 February 2013, A/HRC/22/53, paras 69-70.

${ }^{69}$ CRPD Committee, General comment on article 19: Living independently and being included in the community, 29 August 2017, CRPD/C/18/1, para 18.
} 
services, including personal assistance' ${ }^{70}$ Such services 'are not restricted to services inside the home, but must also be able to extend to the spheres of employment, education or political and cultural participation'. ${ }^{71}$ Autistic people, for instance, require the provision of whatever support can be achieved, through house services, adapted communication and adequate training, that is fully embedded in the places where they live. The right to independent living is contingent on resolving issues related to economic and social rights. ${ }^{72}$ Should these issues be ignored, disabled people will remain segregated and the right to independent living remain a dead letter. The result is that it makes no sense to assign this right, or even parts of it, to only one of the different categories of human rights, because it results from an overlapping of such categories.

The second example that illustrates the blurring of the distinction between the two sets of rights in the CRPD is the right to inclusive education. While education is commonly said to belong to economic and social rights, ${ }^{73}$ it also pertains to civil and political rights (through the right of parents to choose the education of their children). ${ }^{74}$ From the outset, it is an example for attesting the indivisibility of human rights. ${ }^{75}$ By proclaiming the right to inclusive education, the CRPD further expanded upon this indivisibility. Article 24 of the CRPD provides that States Parties must 'ensure an inclusive education system at all levels and lifelong learning' ${ }^{76}$ According to the CRPD Committee, the right to inclusive education requires that they adapt 'educational environments to accommodate the different requirements and identities of individual students'. ${ }^{77}$

This new emphasis on inclusion has led to an even greater overlap of both sets of rights, as it implies that schools should recognize and value pupils' varied characteristics. By providing that the inclusive education system to be established must enhance 'respect for ... human diversity', ${ }^{78}$ the Convention seeks to encourage greater acceptance of distinct forms of embodiment. Deaf people, for instance, who consider themselves a linguistic community, see in sign language more than a tool of communication. ${ }^{79}$ The CRPD provides that States Parties must facilitate 'the promotion of the linguistic identity of the deaf community' to achieve their full participation in education. ${ }^{80}$ While the Convention is sometimes interpreted as authorising segregated or separate education for those who are deaf, ${ }^{81}$ it does protect them against forced assimilation. The right to inclusive education requires that States Parties ensure both equal access to education and equal respect for human differences. This right no longer just includes

\footnotetext{
${ }^{70}$ Art 19(b), CRPD.

${ }^{71}$ CRPD Committee (n 69) para 29.

72 Open Society Foundations (OSF), A Community for All: Implementing Article 19 - A Guide for Monitoring Progress on the Implementation of Article 19 of Convention on the Rights of Persons with Disabilities (OSF 2011) $14<$ https://www.opensocietyfoundations.org/sites/default/files/community-for-all-guide-20111202.pdf $>$.

${ }^{73}$ Art 13 and 14, ICESCR.

${ }^{74}$ Art 18(4), ICCPR.

75 See $\mathrm{n} 34$.

${ }^{76}$ Art 24(1), CRPD.

77 CRPD Committee, General Comment No 4. Article 24: Right to inclusive education, 2 September 2016, $\mathrm{CRPD} / \mathrm{C} / \mathrm{GC} / 4$, para 9.

${ }^{78}$ Art 24(1)(a), CRPD.

${ }^{79}$ S Batterbury, 'Language justice for Sign Language Peoples: the UN Convention on the Rights of Persons with Disabilities' (2012) 11 Language Policy 256-8.

${ }^{80}$ Art 24(3)(b), CRPD. See also Art 30(4), CRPD and CRPD Committee (n 77) para 56.

${ }^{81} \mathrm{G}$ de Beco, 'The Right to Inclusive Education According to Article 24 of the UN Convention on the Rights of Persons with Disabilities: Background, Requirements and (Remaining) Questions' (2014) 32 NQHR 286; O Arnardóttir, 'The Right to Inclusive Education For Children With Disabilities - Innovations In the CRPD' in A Eide, J Möller and I Ziemele (eds), Making Peoples Heard Essays on Human Rights in Honour of Gudmundur Alfredsson (Martinus Nijhoff Publishers 2011) 219-20.
} 
aspects of both civil and political and economic and social rights, but culminates in a blending of the two sets of rights.

\section{B. The Indivisibility of Human Rights and Disabled People}

Consequently, the indivisibility of human rights is something that matters a great deal in the context of disability. The CRPD calls for measures to give them control over their lives and at the same time foster their inclusion into society. It is therefore not by chance that the Convention has done away with the distinction between the two sets of rights. As noted by Mégret, this distinction has done a disservice to disabled people. ${ }^{82}$ The fact that the indivisibility of human rights has added value was indeed assumed in the past, but the CRPD reveals that treating human rights indivisibly is imperative so that disabled people can benefit fully from these rights.

It is worth noting that earlier international legal instruments had a prevailing welfarist approach to the issue of disability ${ }^{83}$ Although this approach has been revoked with the adoption of the CRPD, the use of resources is still relevant in order to protect the human rights of disabled people. More broadly, it has even been claimed that welfare can be more efficient than human rights when it comes to increasing well-being. ${ }^{84}$ The Convention has found a middle way by adopting an approach that consolidates but surpasses the welfarist approach. The removal of barriers involves the input of resources, although this is not the main purpose. ${ }^{85}$ The CRPD aims to give disabled people 'the full and equal enjoyment of all human rights' ${ }^{86}$ which of course depends on but requires more than the adoption of welfare policies.

The situation is now such that it is impossible to classify the rights protected by the CRPD as belonging either to civil and political rights or to economic and social rights. The indivisibility of human rights postulates the necessity of cutting across any such categorization. This allows the correction of the idea that both sets of rights are concerned with different areas of life and that these sets of rights are only superficially interconnected, which idea led to a prioritization between them. In the same way as has been argued with regard to women, ${ }^{87}$ the acceptance of the privileged position of civil and political rights has been detrimental to disabled people. Should the socio-economic dimension be left aside and forgotten, these rights would be empty of content. It is therefore imperative that a deeper connection between the two sets of rights be acknowledged. Failure to acknowledge this deeper connection fails to take into account the situation of disabled people and thwarts their full participation in society.

The result is not only that the CRPD has placed both sets of rights on an equal footing but also that the very existence of the division into civil and political and economic and social rights has itself become a hindrance to the correct interpretation of the Convention. While human rights more often than not have been related individually to these sets of rights, the CRPD disaggregated the different categories of human rights throughout its different provisions.

This new appreciation of the indivisibility of human rights is not only a matter of proper implementation. International human rights law has incorporated the two sets of rights into the

\footnotetext{
${ }^{82}$ F Mégret, 'The Disabilities Convention: Towards a Holistic Concept of Rights' (2008) 12 IJHR 265.

${ }^{83}$ GA, Declaration on the Rights of Mentally Retarded Persons, 20 December 1971, A/RES/26/2856; GA, Declaration on the Rights of Disabled Persons, 9 December 1975, A/RES/3447 (XXX).

${ }^{84}$ E Posner, 'Human Welfare, not Human Rights' (2008) 108 CLR 1775-82.

${ }^{85}$ Mégret (n 82) 265-6.

${ }^{86}$ Art 1, CRPD.

${ }^{87}$ R Johnstone, 'Feminist Influences on the United Nations Human Rights Treaty Bodies' (2006) 28 HRQ 14950 .
} 
various rights protected by the Convention. This development not only affects the implementation of human rights but also strengthens their interrelationship further as well as puts into question the very categorization of human rights into two distinct sets of rights. The CRPD has provided a more far-reaching and comprehensive way of understanding indivisibility that bears precisely upon the content of human rights. The crux of the issue is that the two sets of rights have become inseparable to the point of making any attempt to apply such a division to be pointless. Both sets of rights are co-essential as human rights of disabled people. Such understanding recognizes not only that the distinction between the two sets of rights is artificial but also that all human rights have different features that can include civil, political, economic, social, cultural as well as other dimensions, and that all these dimensions are always inter-joined.

However, this is at odds with actual international human rights law. Since Article 4(2) of the CRPD is only applicable to economic and social rights, States Parties must be told which rights belong to this category under the Convention. Since no definite answer can be given to resolve this issue (which will be examined in greater depth in section III), other solutions must be found. One of these solutions is to identify just what aspects of a particular right fall under the remit of either civil and political or economic and social rights. ${ }^{88}$ This solution is again unfortunately mistaken. Dissecting the Convention rights may perhaps lead to formal recognition but not to practical enjoyment. These rights are too hybrid to be successfully vindicated by such an artificial device. ${ }^{89}$ In the examples of rights given earlier, the choice of place of residence is hollow if autistic people cannot freely opt for living arrangements other than in institutions, because these are the only places where their particular needs can be adequately met or because the applicable legislation makes the assistance required inaccessible elsewhere. Similarly, the goal of inclusive education is worthless if deaf children must adapt to school by being obliged to give up aspects of their cultural identity that ties them to their deaf peers who may of course include their own parents. And all of this while leaving aside the question of general obligations, including the duty to provide reasonable accommodation. As a result, civil and political and economic and social rights have unexpectedly become indistinguishable within the CRPD. They have become so interwoven that fracturing them undermines the whole of the Convention.

The proclamation that '[a]1l human rights are universal, indivisible and interdependent and interrelated' and recognition of obligations to respect, protect and fulfil have drawn special attention to the interrelationship between civil and political and economic and social rights. The CRPD has pressed ahead with this development, and even made any categorization of human rights into two distinct sets of rights difficult to carry out. This Convention thus represents the next step of a movement that has been unravelling the distinction between the two sets of rights. This is not an isolated phenomenon, but one that characterizes the CRPD as a whole. By exceeding a number of established distinctions in the field of international human rights law, the Convention has brought out a more holistic view of human rights. ${ }^{90}$ Human rights must be seen ever more as a single entity if they are not to be deprived of real meaning. This way of understanding indivisibility does not just attribute equal value to both sets of rights or argue that these sets of rights are actually intertwined, but reflects the idea that they are mutually inextricable from each other.

\footnotetext{
${ }^{88}$ This is what the CRPD Committee proposed with the right to independent living (CRPD Committee (n 69) para 39).

${ }^{89}$ Flóvenz (n 61) 267.

${ }^{90}$ Mégret (n 58) 524.
} 


\section{THE REAL AND ACTUAL ENJOYMENT OF HUMAN RightS}

The fact that States have not been able to agree upon the methods of implementation for civil and political and economic and social rights eventually led to the adoption of both the ICCPR and the ICESCR. It crystallized a division of human rights into two sets of rights, which emerged as a result of an ideological divide in the aftermath of World War II. Western States' dismissal of economic and social rights would, however, have been a 'myth' fabricated by the Cold War. ${ }^{91}$ These rights have been losing attraction since the 1970 s, although they have roots that go back as far as the French Revolution and even the Magna Carta. ${ }^{92}$

Following this, the categorization of human rights into two distinct sets of rights has been associated with the State as being either the enemy or the provider. This accentuated the dichotomy between 'positive obligations', on the one hand, and 'negative obligations', on the other. As notably advanced by Berlin, ${ }^{93}$ freedom has been considered to be either positive or negative. ${ }^{94}$ Nonetheless, the dichotomy between 'positive obligations' and 'negative obligations' is hit by reality. It is difficult to distinguish between both kinds of obligations when it comes to policy-making. The implementation of human rights always raises questions with regard to the distribution of resources. ${ }^{95}$

As a result, the central issue is not whether but how States should use their resources to meet their human rights obligations. Whether they have reached the objective requires that attention be paid to both the amount of expenditure and the generation of revenues. ${ }^{96}$ The resources to be taken into account moreover include not only financial, human and natural resources but also the national and international resources potentially available. ${ }^{97}$ As this is a continuing process, it is essential to appeal to monitoring devices that can offer an accurate picture of efforts undertaken, such as indicators and budget analysis.

However, the ICESCR provides that economic and social rights must be realized progressively within the State's available resources. ${ }^{98}$ The notion of progressive realization applies only to these rights, as the ICCPR makes no such provision. This notion in fact represents an escape hatch for States, as it provides an excuse for the evasion of their

\footnotetext{
91 D Whelan and J Donnelly, 'The West, Economic and Social Rights, and the Global Human Rights Regime: Setting the Record Straight' (2007) 29 HRQ 946. See however L Kang, 'The Unsettled Relationship of Economic and Social Rights and the West: A Response to Whelan and Donnelly' (2009) 31 HRQ 1009-13; D Whelan and J Donnelly, 'The Reality of Western Support for Economic and Social Rights: A Reply to Susan L Kang' (2009) 31 HRQ 1047-9; A Kirkup and T Evans, 'The Myth of Western Opposition to Economic, Social, and Cultural Rights? A Reply to Whelan and Donnelly' (2009) 31 HRQ 226-7.

${ }^{92}$ W Osiatynski, Human Rights and Their Limits (Cambridge University Press 2009) 36; C O'Cinneide, 'Austerity and the Faded Dream of a 'Social Europe" in A Nolan (ed), Economic and Social Rights after the Global Financial Crisis (Cambridge University Press 2014) 170-1; G Van Bueren, 'More Magna than Magna Carta: Magna Carta's Sister - the Charter of the Forest' in R Hazell and J Melton (eds), Magna Carta and its Modern Legacy (Cambridge University Press 2015) 196.

${ }^{93}$ I Berlin, Four Essays on Liberty (Oxford University Press 1969) 121-2 and 131-4.

94 There are however differences between the two concepts, since positive freedom involves giving increased powers to the State whereas positive obligations emphasize the steps to be taken with a view to guaranteeing human rights.

${ }^{95}$ E Posner, The Twilight of Human Rights Law (Oxford University Press 2014) 89-90; D Garland, 'On the Concept of 'Social Rights" (2016) 2 Soc Leg Stud 626; J Griffin, On Human Rights (Oxford University Press 2008$) 169$. 96 B Saul, D Kinley and J Mowbray, The International Covenant on Economic, Social and Cultural Rights: Commentary, Cases, and Materials (Oxford University Press 2014) 143-4.

${ }^{97}$ A Kendrick, 'Measuring Compliance: Social Rights and the Maximum Available Resources Dilemma' (2017) HRQ 657; S Skogly, 'The Requirement of Using the "Maximum of Available Resources" for Human Rights Realisation: A Question of Quality as Well as Quantity?' (2012) 12 HRLR 393; R Robertson, 'Measuring State Compliance with the Obligation to Devote the "Maximum Available Resources" to Realizing Economic, Social, and Cultural Rights' (1994) 16 HRQ 693.

${ }^{98}$ Art 2(1), ICESCR.
} 
commitments, thereby playing the part of a 'monstrous serpent' in international human rights law. This explains why reflection on various ways to determine whether States are actually following through on these commitments has tended to concentrate on economic and social rights. Conversely, the ICCPR ignores the demand that civil and political rights need de facto to be realized even if they are de jure violated. The unavailability of resources will not affect the potential breach of legal obligations. The focus, therefore, is on the occurrence of such breach notwithstanding the necessity of going further with the purpose of meeting these legal obligations. This raises the question why social and economic rights are the only ones to be subject to progressive realization. ${ }^{99}$ The problem is that the notion in question is tied up with those rights through the ICESCR.

In the end, it does remain necessary to know which category a particular right belongs to. It is nevertheless suggested that such knowledge cannot be obtained, especially with the CRPD. As shown in the previous section, it is hardly feasible to locate any right protected by this Convention to either side of the division into the two sets of rights. While this could be done for particular aspects of one of the Convention rights, assigning such a right to either set of rights in this way runs the risk of disavowal as it not only inhibits its realization but also undercuts the very freedom that that right aims to provide for. The CRPD recognizes that the implementation of human rights will continue to be restricted if disabled people are unable to exercise these rights. Although pursuing the division into two sets of rights might be done at an abstract level, it faces serious obstacles with respect of its application.

As a result, the differentiation between duties of immediate application and duties of progressive realization has proven to be immaterial. While human rights entail both kinds of duties at the same time, it turns out to be impossible to place them in any category of rights so as to uphold such differentiation. The solution is not to relinquish the notion of progressive realization which, on the contrary, should be more deeply and more fully appreciated. Rather, it means extending the methodologies that support this notion to the entire field of human rights.

Rather than dwelling on positive and negative obligations with civil and political and economic and social rights somehow in the background, it is necessary to appreciate how existing 'regulatory regimes' lead to acute forms of marginalization. ${ }^{100}$ The question is no longer whether the State is friend or foe; rather, it is the very legitimacy of the State that must come under scrutiny. States need to recover this legitimacy, which has been gradually lost by the rejection of the 'tradition of the virtues'. ${ }^{101}$ As argued by Van Parijs, 'real' freedom is not a question of protecting positive or negative freedom but of securing a similar level of opportunities for everyone. ${ }^{102}$ This points to the necessity of insisting on the practical benefits of a freedom that may vary according to the circumstances.

As demonstrated by the CRPD, the advent of group-specific human rights treaties has accelerated such a way of thinking about indivisibility. These human rights treaties require greater sensitivity to the particular characteristics of certain individuals whose needs call for measures that go beyond the formal recognition of human rights. By guaranteeing appropriate support towards this end, the CRPD has given more tangible effect to the indivisibility of human rights. What had come to matter is the real and actual enjoyment of these rights regardless of any categorization.

\footnotetext{
99 J Nickel, Making Sense of Human Rights (2nd edn, Blackwell Publishing 2007) 151; De Schutter (n 7) 527.

${ }^{100}$ C Sheppard, 'Indignation, Socio-economic Inequality and the Role of Law' (2015) 5 Oñati Socio-legal Series 240.

${ }^{101}$ A MacIntyre, After Virtue (Duckworth 1985) 255.

102 P Van Parijs, Real Freedom for All: What (if Anything) Can Justify Capitalism? (Oxford University Press 1995) 22-3 and 28.
} 
Such an understanding of indivisibility could lead to another way of approaching the implementation of human rights. What would matter is no longer the timing of the implementation of these rights, i.e. whether now or later, but the effectiveness of doing so, i.e. the guarantee that these rights can in fact and in reality be exercised. The European Court of Human Rights understood this very early on when it declared that the European Convention on Human Rights (ECHR) 'is intended to guarantee not rights that are theoretical or illusory but rights that are practical and effective'. ${ }^{103}$ The effectiveness of human rights implementation means that the actual exercise of such rights must be brought to the fore. The debate must not only concern the allocation of the resources necessary to reach that goal, which is where it usually stops, but must also discuss political arrangements towards this end. The requirement to provide enabling conditions for the exercise of human rights thus gives a socio-economic dimension to classical 'liberal' rights. ${ }^{104}$

What is therefore important is to create a shift in focus by examining the means of improving the practical enjoyment of human rights. The true question that States must ask themselves is what to do in order to guarantee that human rights makes sense for individuals whatever the situation they may be in. This requires consideration not only of disability, race, gender, age, and sexual orientation but also of poverty, environment, dependency, participation and any other human rights issues that require special attention.

In order to achieve this, human rights should be understood as each and every human right. For too long, human rights have received a narrow interpretation that moves economic and social rights to the background. The dichotomy between 'positive obligations' and 'negative obligations' originated from the desire to differentiate civil and political from economic and social rights, though it subsequently served to demonstrate that the two sets of rights call for similar kinds of obligations. Meanwhile, it has left a legacy that persistently lowers the status of economic and social rights. The necessity to root those rights more firmly into international human rights law is as pressing now as ever.

The proposed understanding of the indivisibility of human rights may help for this purpose, since it can contribute to teasing out the nexus between the notion of human rights and civil and political rights. This counsels restraint from any alignment of the content of human rights with particular categories of human rights. It also discourages leaning upon these categories in order to differentiate what must be achieved both now and over time.

One possible objection to this way of understanding the indivisibility of human rights is that it may result in economic and social rights fading even further into the background. The answer to this objection is that drawing greater attention to these rights appears to have yielded limited results with regard to their implementation. Obligations deriving from economic and social rights, by and large, continue to be evaded. ${ }^{105}$ The reason is that continual reference to the different categories of human rights can make for a tacit denial of their equal status. Employing such categories gives leeway to the pretence that these categories have divergent foundations. ${ }^{106}$ While these foundations are in fact shared, ${ }^{107}$ arguing for antagonistic foundations provides moral grounding for giving some rights more value than others. As stated by the Special Rapporteur on Extreme Poverty and Human Rights, '[a] conception of human rights that implicitly accepts a radical hierarchical distinction between the two sets of rights ...

\footnotetext{
103 Airey v Ireland, Application No 6289/73, Judgment of 9 October 1979, para 24.

$104 \mathrm{~J}$ Anderson and A Honneth, 'Autonomy, Vulnerability, Recognition, and Justice' in J Christman and J Anderson (eds), Autonomy and the Challenges to Liberalism: New Essays (Cambridge University Press 2005) 129.

105 P O'Connell, 'Let them Eat Cake: Socio-Economic Rights in An Age of Austerity' in A Nolan, R O'Connell and C Harvey (eds), Human Rights and Public Finance: Budgets and the Promotion of Economic and Social Rights (Hart Publishing 2013) 60-1 and 66.

106 Whelan (n 49) 210.

${ }^{107}$ C Gearty and V Mantouvalou, Debating Social Rights (Hart Publishing 2010) 98-107.
} 
is one that is fundamentally incompatible with international human rights law'. ${ }^{108}$ Hence, admitting that human rights are indivisible, as is sought here, and moreover acting accordingly might outweigh the purported beneficial effects of upholding their categorization into two distinct sets of rights.

\section{CONCLUSION}

This article examined the indivisibility of human rights in light of the CRPD. Back in 1952, the so-called 'Separation Resolution' provided that there would be separate human rights treaties for civil and political rights, on the one hand, and economic and social rights, on the other. ${ }^{109}$ The resultant division into two sets of rights was primarily aimed at their legal enforceability. The article has advanced a concept of indivisibility which dismantles this division even more. The CRPD can be seen as a further stage in undermining the injudicious categorization of human rights. While repeating the mantra that human rights are 'universal, indivisible, and interdependent and interrelated' does not by itself make it come true, this article has suggested that the Convention provides a more powerful insight into the indivisibility of human rights.

The article argues that the CRPD has generated a new understanding of the indivisibility of human rights insofar as it considers civil and political and economic and social rights as inextricably bound together. It has shown both how the Convention has led to the blurring of the distinction between the two sets of rights and how the blurring of this distinction has recast the way indivisibility needs to be understood. It has also analysed the problems caused by this new appreciation of indivisibility, especially with regard to the notion of progressive realization, and highlighted the consequent demand to put a greater emphasis on the actual and real enjoyment of human rights. This new understanding of the indivisibility of human rights could accelerate attention in scholarship on all matters affecting the exercise of these rights, because it makes it of supreme importance to pursue the effectiveness of their implementation. Such a move can even be a stepping stone towards elevating the position of economic and social rights under international human rights law.

In 1941, Roosevelt made his State of the Union Address and laid out what for him were the four essential freedoms for a better world: 'freedom of speech, freedom of worship, freedom from want and freedom from fear'. Not only did he mention 'freedom from fear' last on this list but he never suggested realizing any one of these freedoms by using restriction or interference. Nor did he consider that one or another of these four freedoms required any particular system of government, as long as States did not contradict these freedoms. The 'Four Freedom Speech' assumed that all human rights must be integrated so that people can live in security in the broadest sense. This is the genuine underpinning of international human rights law.

\footnotetext{
108 P Alston, Report of the Special Rapporteur on Extreme Poverty and Human Rights, 28 April 2016, $\mathrm{A} / \mathrm{HRC} / 32 / 313$, para 63 (emphasis added).

${ }^{109}$ GA, Res 543 (VI), 5 February 1952, A/RES/543(VI).
} 